\title{
A Recent History of Government Responses to Constitutional Litigation
}

\section{Carissima Mathen*}

The 2006 Canadian federal election, which brought the Conservative Party ${ }^{1}$ to power for the first time, shifted the dynamics of constitutional advocacy. The government adopted a combative litigation posture, channeled through aggressive political messaging and uncompromising choices. Since the return to power in 2015 of the Liberal Party, many expect a more respectful attitude towards litigants, the courts and the Constitution. Certainly, the new government appears more positively disposed to constitutional rights and judicial review. As a result, Canadians are less likely to witness an openly hostile attitude towards the judiciary. ${ }^{2}$ That said, it is impossible to predict the precise way that the new government will respond to constitutional litigation.is likely.

The observations that follow largely focus on government responses to final judicial settlement of constitutional disputes. But there is, as well, much to be gleaned from how a government conducts itself during litigation. While the latter issue does not feature prominently in this paper, it informs some of the concluding comments.

\section{A Continuum of Government Responses}

Government responses to constitutional losses ${ }^{3}$ can range from outright defiance to wholehearted embrace. Outright defiance by state actors is rare, ${ }^{4}$ and the former Conservative gov- ernment did not routinely engage in it. Nevertheless, the government consistently displayed a readiness to test the constitution's limits. ${ }^{5}$ One example is Prime Minister Stephen Harper's announcement of a moratorium on Senate appointments. Having been frustrated in his attempts to reform the Upper House, ${ }^{6}$ Harper declared that his authority to "appoint" Senators meant that he could refuse to appoint them at all. $^{7}$

Harper's position was almost certainly unconstitutional. ${ }^{8}$ Indeed, given that the judicial appointment power involves an area - executive discretion - where judges tend to tread carefully, the gambit may have been a dare to the courts to intervene. ${ }^{9}$ It is fair, therefore, to characterize the July 2015 statement as embodying a kind of defiance.

Defiance can be expressed through political as well as legal action. The federal Conservatives employed political tactics on numerous occasions. In June of 2015, the then Minister of Health Rona Ambrose denounced a Supreme Court decision, R. v. Smith, ${ }^{10}$ which found that criminalizing the possession of non-dried forms of medical marijuana violates section 7 of the Charter of Rights and Freedoms. ${ }^{11}$ Describing herself as "outraged", Ambrose accused the Court of trying to "normalize" drug use. ${ }^{12}$

Politics were similarly on display in an op-ed penned by former Minister of Justice Peter 
MacKay following the Nur decision. ${ }^{13}$ In that case, the Supreme Court held that certain mandatory sentences for firearms possession amounted to cruel and unusual punishment. MacKay wrote that the Court had used "a far-fetched hypothetical scenario" to mischaracterize a good law "designed to take gang members and those who seek to commit violent gun crime off the streets" as a bad one that would "impact law-abiding firearms owners." ${ }^{14}$ He took particular exception to the idea that a Conservative sentencing initiative could be turned against "law-abiding hunters, farmers and sport shooters." ${ }^{15}$

The most egregious example of "playing politics" were the allegations and insinuations made against the Chief Justice of Canada in the wake of the botched appointment to the Supreme Court of Justice Marc Nadon. After months of controversy, ${ }^{16}$ the Court advised that Nadon's appointment was void $a b$ initio. ${ }^{17}$ Incensed members of the Conservative caucus told reporters that the Chief Justice had lobbied against Nadon. The Prime Minister's Office even intimated that she had tried to meddle in the appointment. ${ }^{18}$ The entire affair was a low point for executive-judicial relations in Canada.

Moving along the spectrum, another government response is to do the bare minimum to comply with a decision, but take other steps to frustrate its spirit. In this category, one can place Canada (Attorney General) v. PHS Community Services Society. ${ }^{19}$ In PHS, the Supreme Court issued an unusual mandamus order to the Minister of Health requiring him to grant a statutory exemption from prosecution for employees of a Vancouver supervised injection clinic. ${ }^{20}$ After complying, the government amended the CDSA so that future exemption requests would require a prohibitively detailed and onerous application. ${ }^{21}$ The government did not repeal the exemption scheme outright, but it set up significant roadblocks to the approval of additional sites. ${ }^{22}$

It appears that the new Liberal government's response to the Supreme Court ruling in Carter v. Canada ${ }^{23}$ reflects a similar tendency. Carter was a challenge to sections 14 and 241 of the Criminal Code which, respectively, prohibit anyone from consenting to the infliction of death, or from aiding and abetting someone to commit suicide. In a decision issued against the former Conservative government, the Court held that the provisions violated section 7 of the Charter to the extent that they applied to competent adults who clearly consent to the termination of life and who have a grievous and irremediable medical condition that causes enduring and intolerable suffering. ${ }^{24}$ The Court granted a 12 -month suspension, which on request of the current Liberal government was extended by a further four months.

In April of 2016, the Liberal government introduced a bill ${ }^{25}$ to amend section 241 of the Code to provide an exemption from punishment where assistance in dying is provided by a physician or nurse practitioner, following numerous safeguards, to a competent adult who meets a new definition of "grievous and irremediable condition." 26 Bill C-14 received royal assent in June, 2016 and a Charter challenge was filed shortly thereafter. ${ }^{27}$ In my opinion, which was shared by others, the government's definition of "grievous and irremediable" fell short of the parameters set forth in Carter which are required to make any subsequent law consistent with section $7 .^{28}$ In particular, the government's decision that any condition must be incurable and a patient's death be reasonably foreseeable ${ }^{29}$ continues to criminalize acts that the Supreme Court has held may not be subject to criminal punishment. ${ }^{30}$

In introducing Bill C-14, the federal government was working under a tight timeframe not of its own making. ${ }^{31}$ Members of the Liberal government repeatedly indicated their desire to strike the correct balance between the various rights and interests implicated in assisted dying. ${ }^{32}$ Whether the government intends to frustrate the spirit of the Carter decision is a close question the answer to which must await the outcome of future litigation. But it is clear that the government elected to take a narrow approach which may prove to be constitutionally suspect. ${ }^{33}$

Yet another response is to withdraw from the field. The federal government appears to have adopted that approach in the areas of securities regulation ${ }^{34}$ and assisted human reproduction. ${ }^{35}$ In each area, the government referred legisla- 
tion to the Supreme Court which subsequently advised that the proposed regime ran afoul of the division of powers. Rather than returning to the drawing board, which would require provincial cooperation, the government stuck with the status quo. ${ }^{36}$

Occasionally, a government treats a loss as an opportunity. The response to Canada $v$ Bedford is a good example. ${ }^{37}$ In Bedford, the Supreme Court held that several prostitution-related crimes violated section 7 of the Charter and were not saved under section $1 .{ }^{38}$ In its reasons, the Court emphasized the fact that the exchange of sex for money was not itself criminally prohibited. ${ }^{39}$ That fact had undermined the then Conservative government's attempt to describe the legislative objectives as punishing or deterring sex work because of its inherent wrongfulness. Instead, the Court balanced the rights violations against a desire to prevent nuisance; ${ }^{40}$ and protect sex workers from exploitation. ${ }^{41}$ The Court ultimately found the impugned provisions invalid. Its analysis, though, implied that, were prostitution itself prohibited, that would trigger an altogether different balancing exercise.

The Conservative government used the 12-month suspension of invalidity to enact a series of sweeping legislative changes. ${ }^{42}$ The government adopted an asymmetrical approach, criminalizing the buying but not the selling of sex. It also tried to discourage what it described as the "commodification" of sex and the "objectification" of the human body. ${ }^{43}$ In the legislation's preamble, the government explicitly articulated a commitment to "equality and human dignity", and a belief that prostitution is consistent with neither. The legislation received royal assent just before the suspension's expiry.

In Bedford, we see how an adverse ruling can provide a significant political opening. For three decades, the issue of prostitution failed to attract federal attention. It is difficult to imagine a situation short of the Bedford decision that would have prompted such focussed action. The Conservative government was able to utilize the Court-imposed delay to catapult the issue of sex work to the top of Parliament's agenda, and revamp the law to reflect a particular brand of legal moralism. Thus, the loss arguably enabled the government to achieve something that was of great political value.

The Conservative government is not alone in treating unfavourable legal developments as opportunities. Consider the law reform initiatives vis-à-vis sexual assault in the 1990s. In 1991, the Supreme Court struck down the original rape shield provisions in the Criminal Code. ${ }^{44}$ In the place of those statutory provisions, the Court crafted a common law framework to govern trial judges' decisions over the admissibility and relevance of sexual history evidence. ${ }^{45}$ The Progressive Conservative ${ }^{46}$ government initiated a broad consultation process leading to a significant overhaul of the Criminal Code. ${ }^{47}$ When the new law was challenged, the Court upheld it. ${ }^{48}$ The pattern repeated a few years later, this time under the federal Liberals, in a constitutional battle over the relevance and admissibility of sexual assault complainants' confidential records. ${ }^{49}$

Though it is unusual for a government to respond positively to a court loss, such a reaction has been known to occur and, perhaps understandably, is especially likely when the loss involves a government's political predecessor. For example, the current Liberal government withdrew the previous government's leave to appeal application in relation to Zunera Ishaq, a woman who challenged a rule that she remove her niqab in order to take the oath of citizenship. In its announcement, the Liberal government said that it had decided to "uphold and respect the decisions" of two lower courts that had ruled in Ishaq's favour. ${ }^{50}$ A separate Liberal decision to reverse the elimination of refugee health care benefits relied expressly on a federal court decision that found the prior Conservative policy to constitute "cruel and unusual treatment." 51 In both cases, the Liberal government found a clear advantage in not seeking to reverse losses meted out to their political rivals. ${ }^{52}$

Finally, in the face of a court loss, a government may elect to do nothing. That is, it not only declines to challenge a negative decision, but also refuses to formally recognize it. The "do nothing" response has become distressingly common in criminal law. As a result, the Criminal Code 
is littered with provisions already found to be unconstitutional. ${ }^{53}$ While a tactic of indifference does not directly challenge a judicial decision, it conflicts with the doctrine of fair notice and undermines the principle of legality. It is, therefore, problematic. ${ }^{54}$

\section{Lessons and Expectations}

The foregoing discussion shows that a multitude of factors shape governmental responses to a constitutional loss. Specific doctrinal concerns about the law's coherence, or broader social values, rank fairly low on the list. A government is far more likely to be motivated by the opportunity to create or exploit a political advantage, by the pressure exerted by past promises, or by the perceived need to secure or expand its support.

The factors operate regardless of a government's political leanings. But there was something distinctive in the Conservative government's long-standing opposition to the type of judicial review ushered in by the Charter. ${ }^{55}$ Over the last decade Canadians saw more openly ideological resistance to the court than from any government in living memory.

It seems unlikely that the current Liberal government will adopt a similar attitude. Such a tonal shift certainly will be positive for the overall relationship between the government and the judiciary. Indeed, it could promote a healthier constitutional order. But it is obvious that all governments seek to shore up political advantage and avoid political costs,. In its first year, the Liberal government has indicated a commitment, at least rhetorically, to constitutional and Charter values. ${ }^{56}$ But advocates would be wise to temper expectations, if only because the scale of the challenge is unprecedented. Nowhere is that challenge more prevalent than in criminal law, where the Conservative government ushered in a markedly punitive, constitutionally suspect regime. We should not be surprised if, instead of taking proactive steps to undo the damage, the current government simply awaits the judicial verdicts that are sure to come. ${ }^{57}$

Those committed to constitutional scrutiny of state action should also recognize that there may be a disconnect between a newly installed Executive and its civil service functionaries a disconnect that can only be ameliorated over time. Executive actors set the tone, but civil servants translate that tone into programmatic and strategic decisions. For example, the Department of Justice provides an advice and defence function that relies heavily on a traditional adversarial posture. That stance, while probably inappropriate when responding to public interest litigation, is unlikely to change.

Again, at this relatively early stage, it is unwise to draw firm conclusions. Indeed, the government is unlikely to adopt a consistent response. For example, the decisions taken by Department of Justice lawyers during the government's motion for an extension of the Supreme Court's delayed remedy in Carter v. Canada were not uniform in their tone and attitude towards constitutional litigation. ${ }^{58}$ As noted above, Carter is the controversial decision narrowing the scope of the criminal prohibition on assisted suicide. In February 2015, the Supreme Court unanimously found the law inconsistent with the Charter, but suspended the remedy for one year. ${ }^{59}$ When Parliament was dissolved in August 2015 in advance of the election, the Conservative government had done little to advance the issue. After it took office in November, the Liberal government announced that it would seek to extend the court-imposed suspension by a further six months.

Some of the government's submissions on the motion appeared outright dismissive of the profound and continuing violation of section 7 that it sought to maintain. For example, federal lawyers sought an expedited leave process. ${ }^{60}$ It characterized the opposition to an extension as strikingly naive. ${ }^{61}$ And it opposed the granting of costs on a full indemnity basis, arguing that the lawyers acting for the Carter plaintiffs had been "amply compensated for their work." ${ }^{2}$ And yet, the government made an important concession - it took no position on Quebec's request that the province be exempted from any further suspension. ${ }^{63}$ A majority of the Court cited the lack of federal opposition when it granted Quebec's request and permitted its "medical aid in dying" 
regime to take effect upon the expiry of the original Carter deadline. ${ }^{64}$

It is, therefore, a reasonable assumption that, over the last decade, any inherent combative tendencies - at the federal level, at least - will have been sharpened to a knifepoint. If there is to be a true shift in government values, it will require a similar shift among the lawyers who manage and litigate its cases.

To conclude, as we contemplate the next chapter in constitutional rights advocacy, citizens, organizations and lawyers must avoid complacency. There remains an abiding need for engagement, public awareness, and, at times, political pressure. We must expect the best, but be prepared for a response that falls somewhat short. For many, the recent change of government at the federal level will feel like the thawing of a deep and dark winter. But as Canadians know only too well, spring is a most inconstant season.

\section{Endnotes}

* Faculty of Law, University of Ottawa.

1 The Conservative Party of Canada was formed in 2003 from the merger of the Progressive Conservative and Canadian Alliance parties.

2 The re-initiation of the Court Challenges Program, which provides federal funding for some Charter challenges, is but one example of a change in the government's attitude. Canada, Office of the Prime Minister, "Minister of Heritage Mandate Letter", (Ottawa: Office of the Prime Minister, 2015), online: <www.pm.gc.ca/eng/minister-canadianheritage-mandate-letter $>$.

3 That said, a "win" may prompt unexpected responses. See Thibaudeau $v$ Canada, [1995] 2 SCR 627, 124 DLR (4th) 449, online: <cra-arc.gc.ca/tx/ ndvdls/tpcs/ncm-tx/spprtpymnts/clm-eng.html> in which the claimants challenged the differential tax treatment of child support paid by one parent (which was deducted from their income) and received by the other (which was included in theirs). The Court, in a 7-2 decision, dismissed the equality claim. The federal government elected to change the rules anyway, so that the transfer of such monies would no longer affect the taxable income for either parent.

4 Often invoked is U.S. President Andrew Jackson's (likely apocryphal) response to Worcester $v$ Georgia 31 US (6 Pet) 515 (1832) In that case the Supreme Court of the United States held that the several Native American tribes enjoyed the status of nations. The President is alleged to have said: "[Chief Justice] John Marshall has made his decision; now let him enforce it." Horace Greeley, The American Conflict: A History of the Great Rebellion in the United States of America Vol I (Hartford, Conn., 1865) 106.Another instance was the refusal, by some U.S. states, to abide by federal court orders mandating school de-segregation: see Cooper v Aaron 358 US 1 (1958).

5 Carissima Mathen and Michael Plaxton, "Pushing It", Policy Options (5 October 2015), online: <policyoptions.irpp.org/issues/october-2015/ stephen-harper-and-the-judiciary/pushingit/> [Mathen and Plaxton, "Pushing It"].

6 Reference re Senate Reform, 2014 SCC 32, [2014] 1 SCR 704.

7 Note that the Constitution Act, 1867 (UK), 30 \& 31 Vict, c 3, reprinted in RSC 1985, Appendix II, No 5 vests the appointment power in the Governor General, albeit exercised on the advice of the Prime Minister. So, by refusing to provide such advice, the Prime Minister was obstructing the Governor General's ability to fulfill his own constitutional responsibilities. Had the moratorium continued and the vacancies increased, the Governor General would have faced four options: decline to appoint, arguably in violation of the Constitution Act, 1867; appoint without advice, in violation of the conventions of responsible government; dismiss the Prime Minister; or resign. See Carissima Mathen, "Gaming the Constitution", Ottawa Citizen (30 July, 2015), online: <ottawacitizen. com/news/politics/carissima-mathen-gamingthe-constitution $>$.

8 The remedy one might expect the courts to grant is another matter.

9 Mathen and Plaxton, "Pushing it", supra note 5. Another example is the former government's decision, in 2013, to simultaneously (a) enact declaratory legislation so that the Supreme Court Act, R.S.C. 1985, c. S-26, ss. 4(1) would be interpreted to permit the appointment of Justice Marc Nadon and (b) initiate a reference to the Court on the interpretation of the original section 6. I have suggested that the curious tactic was caused in part by the government's belief that the Court would never advise that Marc Nadon was 
ineligible (which, of course, it did): Carissima Mathen, "The Shadow of Absurdity and the Challenge of Easy Cases: Looking Back on the Supreme Court Act Reference" (2015) 71 SCLR 161; Reference re Supreme Court Act, ss 5 and 6, 2014 SCC 21, [2014] 1 SCR 433 [Reference re Supreme Court Act].

$10 R v$ Smith, 2015 SCC 34, [2015] 2 SCR 602.

11 Canadian Charter of Rights and Freedoms, s 7, Part I of the Constitution Act, 1982, being Schedule B to the Canada Act (UK), 1982, c 11 [Charter].

12 Angela Mulholland, "Ambrose 'outraged' by SCC's marijuana ruling", CTV News (11 June 2015), online: <ctvnews.ca/canada/ambrose-outragedby-scc-s-marijuana-ruling-1.2417118>.

13 R. v. Nur, 2015 SCC 15, [2015] 1 SCR 773 [Nur].

14 Peter MacKay, "What the court got right and wrong - on mandatory sentences for gun crimes", National Post (21 April 2015), online: $<$ news.nationalpost.com/news/canada/mackayslams-supreme-court-for-quashing-mandatoryminimums-for-gun-crimes>; Tristin Hopper, "Peter MacKay slams Supreme Court for quashing mandatory minimum gun sentences", National Post (22 April 2015), online: <news.nationalpost. $\mathrm{com} /$ news/canada/mackay-slams-supreme-courtfor-quashing-mandatory-minimums-for-guncrimes $>$. It should be noted that the dissenting judges were also highly critical of the majority decision: Nur, supra note 13 at para 133.

15 MacKay, supra note14..

16 Mathen, "The Shadow of Absurdity" supra note 8.

17 Reference re Supreme Court Act, supra note9.

18 John Ivison, "Tories incensed with Supreme Court as some allege Chief Justice lobbied against Marc Nadon appointment", National Post (1 May 2014), online: <news.nationalpost.com/news/canada/ canadian-politics/tories-incensed-with-supremecourt-as-some-allege-chief-justice-lobbied-againstmarc-nadon-appointmen $>$.

192011 SCC 44, [2011] 3 SCR 134 [Insite].

20 SC 1996 c 19 s 56 [CDSA]. The Controlled Drugs and Substances Act granted the Minister a discretion to provide such exemptions where, inter alia, they would be in the public interest.

21 Ibid s 56.1(3)(a)-(z).

22 That is not to say that those roadblocks are necessarily illegal or unconstitutional. See Paul Daly: "The A to Z.1 of Safe Injection Sites in Canada", Administrative Law Matters (6 June 2013) , online: <administrativelawmatters.com/ blog/2013/06/06/the-a-to-z-1-of-safe-injectionsites-in-canada/> .
23 Carter v Canada (Attorney General), 2015 SCC 5, [2015] 1 SCR 331 [Carter].

24 Ibid at para 4.

25 Bill C-14, An Act to amend the Criminal Code and to make related amendments to other Acts (medical assistance in dying), 1st Sess, 42nd Parl, 2016 (as passed by the House of Commons 31 May 2016).

26 <http://www.parl.gc.ca/LegisInfo/BillDetails. asp $x$ ? Language $=E \& M o d e=1 \&$ billId $=8177165>$.

27 Mike Laanela, "Assisted-dying legislation faces new legal challenge in B.C." CBC News, 27 June $2016<\mathrm{http}: / /$ www.cbc.ca/news/canada/ british-columbia/bccla-assisted-dyinglegislation-1.3654220>.

28 Carissima Mathen, "TheExistential Issue of Assisted Dying: From Carter to C-14", Policy Magazine July-August 2016, 46. See also the testimony of Peter Hogg before the Standing Senate Committee on Legal and Constitutional Affairs, 6 June 2016: $<$ http://www.parl.gc.ca/LegisInfo/BillDetails. aspx? Language $=E \& M o d e=1 \&$ billId $=8177165>$.

$29 \mathrm{Ibid}, \mathrm{s} 241.2(2)$.

30 I recognize, though, that in any new challenge the court would have to consider the law's purported objective, which might well impact the section 7 analysis and, in particular, the degree to which further limits could be found to be overbroad.

31 The tight timeframe resulted from the fact that the suspension granted in February 2015 was set to expire on June 6,2016 . Some in the Liberal government claimed they were facing the possibility of a legal "vacuum" that would threaten the rule of law. I have argued that, even if the original suspension had lapsed with no new legislation, no legal vacuum would have occurred; the remedy in Carter would have been incorporated into the still-extant offences: Carissima Mathen, "Carter v Canada: The State of Constitutional Remedies is Really, Really Bad" (Paper delivered at the $19^{\text {th }}$ Annual Osgoode Constitutional Cases Conference, Osgoode Hall Law School, York University, 8 April 2016 [unpublished]). Indeed, after the Supreme Court decided that during the additional four-month suspension superior courts were authorized to grant constitutional exemptions to eligible individuals, those courts began applying the original ruling. See Ontario, Superior Court of Justice, Practice Advisory - Application for Judicial Authorization of Physician Assisted Death, online: <ontariocourts.ca/scj/practice/applicationjudicial-authorization-carter/>.

32 See, for example, the remarks offered in Parliament by the Honourable Jody Wilson-Raybold, 16 
June 2016 10:40 am: <https://openparliament.ca/ bills/42-1/C-14/>.

33 Chantal Hebert, "Liberals have met only bare minimum with assisted-dying bill", Toronto Star (16 April 2016), online: <thestar.com/news/ canada/2016/04/16/liberals-have-met-onlybare-minimum-with-assisted-dying-bill-hbert. html>. For a more supportive view of the law, see Sebastien Grammond, "Parliament isn't bound to 'copy and paste' court rulings into law" Globe and Mail 30 June 2016: <http://www.theglobeandmail. com/opinion/parliament-isnt-bound-to-copyand-paste-rulings-into-law/article30687631/>.

34 Reference re Securities Act, 2011 SCC 66, [2011] 3 SCR 837.

35 Reference re Assisted Human Reproduction Act, 2010 SCC 61, [2010] 3 SCR 457.

36 Here, one could also place the government response to Senate reform.

37 Canada (Attorney General) v Bedford, 2013 SCC 72, [2013] 3 SCR 1101.

38 Ibid at para 2.

39 Ibid at paras 5, 87.

40 Ibid at para 136.

41 Ibid at para 137.

42 Bill C-36, An Act to amend the Criminal Code in response to the Supreme Court of Canada decision in Attorney General of Canada v. Bedford and to make consequential amendments to other Acts, 2nd Sess, 41 st ${ }^{t}$ Parl, 2014 (assented to 6 November 2014) SC 2014, c 25.

43 Ibid.

$44 R v$ Seaboyer, [1991] 2 SCR 577, 83 DLR (4th) 193; R. v. Gayme, 2010 SCC 61, [2010] 3 SCR 457.

$45 \mathrm{Ibid}$. Note that the declaration of invalidity was not subject to any delay.

46 The PC's were one of the precursors to the current Conservative Party of Canada. Supra, note 1.

47 For example, the process led to the first ever definition of "consent" in the context of sexual activity: Criminal Code, RSC 1985 c C-46 ss 273.1, 273.2.

$48 R v$ Darrach, [2000] 2 SCR 443, 191 DLR (4th) 539.

49 R. v. O'Connor, [1995] 4 SCR 411, 130 DLR (4th) 235; $R v$ Mills, [1999] 3 SCR 668, 180 DLR (4th) 1.

50 Susana Mas, "Justin Trudeau's government drops controversial niqab appeal", CBC News (16 November 2015), online: <cbc.ca/news/politics/ niqab-appeal-appeal-citizenship-ceremoniescanada-jody-wilson-raybould-1.3321264>.

51 Janice Dickson, "Liberals drop Harper government's court battle over refugee health benefits" iPolitics (16 December 2015), online: $<$ ipolitics.ca/2015/12/16/liberals-drop-harper- governments-court-battle-over-refugee-healthbenefits/>.

52 And it did so in spite of the fact that the decisions relied on, or articulated, legal principles that might prove unfavourable to the government in future litigation. In the case of Ishaq, the government might have wished to challenge the court's relatively narrow analysis of ministerial discretion. In the refugee health care case, it might have wished to challenge the first instance court's significant expansion of the scope of section 12 of the Charter.

53 See Criminal Code RSC 1985, c C-46, s 17 (compulsion by threats), s 163.1(1) (child pornography), ss 229 (c) and 230 (murder). A dramatic example of the consequences of Parliamentary inaction is $R v$ Vader, 2016 ABQB 505, in which an Alberta judge convicted a man of two counts of second-degree murder under the previously-noted section 230 of the Criminal Code. The Supreme Court found s 230 unconstitutional in 1991, but it had never been excised from the Code. The verdict is under appeal. Paula Simons, "Travis Vader verdict ignites legal firestorm after experts cite error in judge's decision", Edmonton Journal (16 September 2016) online: Edmonton Journal <http://edmontonjournal.com/opinion/ columnists/paula-simons-travis-vader-verdictignites-legal-firestorm-after-experts-cite-error-injudges-decision $>$ (accessed 2 November 2016).

$54 R v$ Nova Scotia Pharmaceutical Society, [1992] 2 SCR 606, 9. DLR (4th) 36. I acknowledge that the principle of legality would not support invalidation of prosecutions under the provision - the existence of a court decision would undoubtedly be considered sufficient to defeat a formal vagueness challenge. Still, government inaction in this regard is unfortunate and, in my view, contrary to any underlying norm of constitutionalism.

55 See also Carissima Mathen, "Choices and Controversy: Judicial Appointments in Canada" (2008) 58 UNBLJ 52, online: <papers.ssrn.com/ sol3/papers.cfm?abstract_id=2221359>.

56 See Canada, Office of the Prime Minister, "Minister of Justice Mandate Letter", (Ottawa: Office of the Prime Minister, 2015), online: <pm. gc.ca/eng/minister-justice-and-attorney-generalcanada-mandate-letter $>$ (The ministerial mandate letters provide some positive indications of a commitment to Charter values, as in the directive to the Minister of Justice to "review our litigation strategy" and render "early decisions to end appeals or positions that are not consistent with our commitments, the Charter or our values."). 
57 The verdicts - many of them unfavourable have begun to arrive: $R v$ Lloyd, 2016 SCC 13, 27 CR (7th) 205; $R v$ Safarzadeh-Markhali, 2016 SCC 14, 27 CR (7th) 265; Canada $v$ Whaling, 2014 SCC 20, [2014] 1 SCR 392.

58 Carter, supra note23.

59 Ibid.

60 Carter $v$ Canada, Motion Record of the Respondent/Applicant Attorney General of Canada filed 3 December 2015 p 61. : <www. scc-csc.ca/case-dossier/info/dock-regi-eng. aspx? cas $=35591>$. The Court rejected the request.

61 Carter $v$ Canada, The Attorney General of Canada, Applicant/Respondents Reply Submissions filed 12 December 2015 para 5: <www.scc-csc.ca/casedossier/info/dock-regi-eng.aspx?cas=35591>.

$62 \mathrm{Ibid}$, para 17.

63 Ibid, para 15.

64 Carter v. Canada (Attorney-General), 2016 SCC 4, 394 DLR (4th) 1. The Quebec legislation is the Act respecting end-of-life care, CQLR c. S-32.0001. 